\title{
Importance of Catering Enterprises' Classification in Service Guality Assessment From the Customer's Point of View. Case of Rezekne City.
}

\author{
Inese Silicka \\ Faculty of Economics and Business \\ ManagementRezekne Academy of \\ Technologies \\ Rezekne, Latvia \\ inese.silicka@rta.lv
}

\author{
Lienite Litavniece \\ Faculty of Economics and Business \\ Management \\ Rezekne Academy of Technologies \\ Rezekne, Latvia \\ lienite.litavniece@rta.lv
}

\author{
Iveta Dembovska \\ Faculty of Economics and Business \\ Management \\ Rezekne Academy of Technologies \\ Rezekne, Latvia \\ iveta.dembovska@rta.lv
}

\begin{abstract}
There are a lot of catering companies offering their services on the market, hence, there is a fierce competition between them. It is essential to provide customers with the appropriate level of service they expect from the respective caterer (restaurant, café, bar, etc.). The aim of the paper is to explore the importance of classification of the catering companies in service quality assessment from the customer's point of view in Rezekne city. The paper is developed within the framework of the RTA scientific grant "Quality Assessment of Rezekne City Catering Companies". Within the grant project, an expert questionnaire was developed to carry out quality assessment of Rezekne city catering enterprises. As a result of the research, it was concluded that the customer service in Rezekne city differs depending on the type of the catering establishment. The monographic, logical constructive, and graphic method, as well as the method of observation (expert questionnaires) were used for the research.
\end{abstract}

Keywords-classification, foodservice, foodservice industry, Rezekne city catering enterprises.

\section{INTRODUCTION}

Food industry is one of the fastest growing industries, and demand in this field increases rapidly. According statistics, revenue in the Food and Beverage industry amounts to US\$107,792 M in 2019 [1] and is expected to grow by 2 percent by 2022 [2].

The history of the catering business dates back to the ancient world, when the emperors of the Ancient Rome spent large sums to satisfy their needs transforming a simple kitchen into a horn of abundance. The catering business was born in the ancient world, experienced its decline in the Middle Ages and its rebirth during the Renaissance, developing to the perfection at the present. Therefore, nowadays there are an infinite number of the catering companies with unique history, traditions, culture, organisation of operations and services, and their offer evolves and develops every year [3].

Dining outside is becoming increasingly widespread, people prefer having meal outside for various reasons, for example, entertainment, festivities, and business [4]. Consequently, during the last five decades the number of catering establishments has grown significantly [5], [6]. Dining at the catering establishments is not a part of daily routine, it can be considered as an important entertainment activity [7].

Defining the problem, the authors believe that every entrepreneur, when providing the services, expects there is a demand. Hence, the customer's satisfaction with a particular service is crucial. Thus, the main goal and task of the entrepreneur is to satisfy the needs and wishes of the clients. In order to meet the customers' desires, the entrepreneur has to find out what is important to the client, still, there is always a great contradiction here, as most people want to get the services at the highest possible quality level at the lowest possible price. In this process, one of the most important factors is the quality that characterises the service.

The aim of the article is to investigate the importance of the classification of catering companies in the service quality assessment from the customer's point of view in Rezekne.

The following tasks were set to achieve the aim:

- To explore classification of the catering businesses;

- To classify Rezekne city catering companies;

- To evaluate catering services offered by Rezekne city caterers.

\section{Materials and Methods}

The article summarises the findings of the authors' research on the quality assessment of Rezekne city catering enterprises. In the paper, the previous researches carried out by the authors, as well as other scientific and practical information was used.

The monographic, logical constructive and 
graphic method, as well as the method of observation (expert questionnaires) were used for the paper. enterprises

Object of the research: classification of catering

Subject of the research: quality assessment of catering services

Hypotheses: evaluation of the catering services' quality depends on the type of catering establishment.

\section{Results AND DISCUSSION}

Catering is a complicated system providing a staff and the equipment in the process of preparing and serving the food [8]. A commonly accepted definition of the term "catering" or "food service" is "the provision of food and beverages away from home" [9]. The tourism and hospitality glossary defines the catering establishment as a place where public or semi-public catering services are provided offering food and beverages for the consumption [10].

Classifying the foodservice industry can be undertaken in a number of ways; one is to split the industry in two sectors [8]. Lillicrap D. and Cousins J. [11] propose to divide the catering enterprises in two sectors - the first, profit orientated businesses for a restricted market segment (transport catering, clubs, private welfare, industrial (contract)) or for the general market (hotels/restaurants, popular catering, fast food, retail stores, pubs and wine bars, etc.), and, the second, cost provision sector (institutional catering, schools, universities and colleges, hospitals, armed forces, prisons) [12]. In addition to the mainstream restaurants, there are also a number of 'unusual' restaurants which seek to differ themselves by offering unique dining experiences. These include suspended or under-sea restaurants, or establishments that are built entirely of ice [13].

An alternative classification is one where the industry is classified according to its business rationale: where foodservice is either the primary goal of the business; where it is part of the overall experience; an 'additional' offer, used to add-value to the business; or where it is either essential or desirable, but not the primary business goal [14].

There are several principles for classification of catering businesses [15], [3], [16]:

1. By functionality (nature of service):

$>$ sales of finished goods;

$>$ sales of finished goods combined with organization of the customer's leisure.

2. By type of production (technical facilities, structure of premises):

$>$ companies working with raw materials, ingredients - a full production cycle;

$>$ companies working with semi-finished products - processing (finishing) companies.

3. By structure of customers (distribution market):

general access - opened type (general market);
$>$ closed type (limited market).

4. By assortment (diversity requirements, technological complexity):

$>$ full service;

$>$ specialised.

5. By type of service:

$>$ waiters/ waitresses;

$>$ self-service;

$>$ mixed type of service.

After studying different classification systems [15], [16], [17], paying particular attention to the profitoriented sector, and studying the organisation of the Rezekne catering companies, the authors have come to the conclusion that the catering services can be as well classified as follows:

- Canteen - a public type company, fast service for a wide range of customers to meet their demands, produces and distributes food according to a varied menu.

Restaurant - an opened type company where catering is combined with organisation of leisure and entertainment. In many Western countries, all catering establishments are called restaurants making a distinction between full-service restaurants (wide choice of food, waiter services); specialised restaurants (fast-food, national cuisine, etc.); selfservice restaurants.

- Café, confectionery - a catering company producing and selling a wide range of hot (coffee, tea, cocoa, hot chocolate) and cold beverages and assortment of desserts, for example, ice cream and confectionery.

Fast-food - catering companies for fast customer service.

- Bar - a small fast service company serving at the counter, offering a wide variety of mixed and pure beverages, as well as some snacks, confectionery. Bars can be classical and specialized. Specialization can be based on the dominant beverage (vodka bar, wine bar, juice bar); musical program (disco bar, jazz bar); customers' interests (sports bar, ladies' bar).

- Buffet - a popular way to cater large groups of people using a minimum number of employees.

- Other catering establishments - mobile catering, catering in public transportation, etc.

Any catering company has a structure of processes including [17]:

- basic processes, the result of which is consumed by the customer (production, customer service, sales, etc.);

supplementary processes that are essential for provision of the basic processes (purchasing ingredients, personnel management, information systems management, etc.).

Two types of production can be distinguished in the catering business. One is production of tangible products (food and beverages), the other - production of intangible 
product (service of providing the finished products to the consumers). Customer satisfaction includes quality of both food and service [18]. Pizam and Ellis [19] review the theory basis underpinning consumer satisfaction.

\section{PRODUCTS OF CATERING BUSINESS}

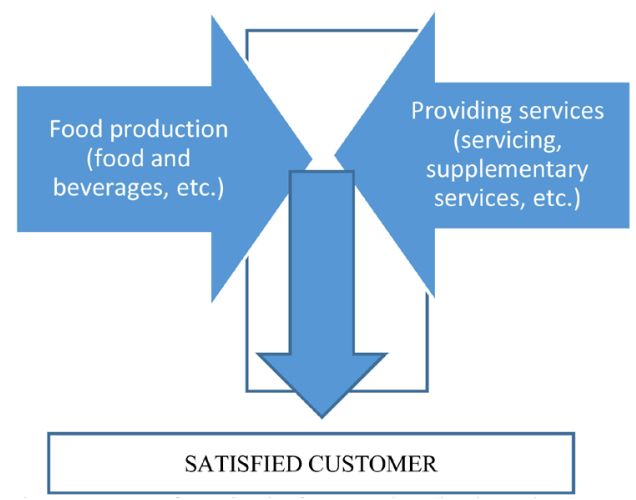

Fig. 1. Nature of catering business product (by the authors)

It can be concluded that the product-forming processes, which determine the production of safe, highquality products and provision of the satisfaction, are crucial in the catering business. The organisation both of information and material flows, or a complex approach, is important for the provision of the services in the company. It is very important to study and analyse the customers' wishes and needs in order to offer a suitable range of food and beverages (tangible product), as well as certain service and supplementary services (intangible product). The share, importance and evaluation of tangible and intangible products vary in the service delivery process. During the flight service, transportation itself will be the most important part of the service, and food as part of the service will be less important, as the customer basically buys transportation rather than meals. In the grocery store, the tangible product itself is important and servicing as well. When choosing a catering company, this proportion will depend on the type of catering company. For the school canteen, food quality, fast service at a low price will be important. At the restaurant, the client wants to receive a high-quality food, high-quality service, taking into account that it will cost more.

Within the framework of the project, from June 2018 to September 2018, classification of Rezekne city catering enterprises and evaluation of the offered services were carried out. The evaluation of the catering companies was based on the observation method (recommended, for example, by I. Millere [17]), which provides that a number of experts make observations, record their observations while actively participating in the process of using the service as a "secret customer", in the result, providing their assessment, conclusions and recommendations on improving the quality of catering services and indicating potential development opportunities for the catering businesses.

In Rezekne city, the catering companies that were evaluated within the study can be classified by combining the above mentioned principles. As a result, in Rezekne city, there are:

- 3 restaurants;

- 4 opened type cafés,

- 11 specialised cafés, including:

○ 1 confectionery concept;

○ 5 fast-food concept;

○ 1 family concept;

- 4 canteen concept;

- 1 pub.

The authors have carried out the service evaluation of 21 Rezekne city catering company using the observation method and have filled in the expert questionnaire, providing the evaluation and recommendations for the elimination of deficiencies and for business development. The expert questionnaire was composed on the basis of the expert questionnaire [20] developed within the Rezekne Augstskola's ESF project "Development and implementation of professional development programs for employees of catering enterprises of hospitality industry". The expert observation questionnaire consisted of seven sections including the following: accessibility, external appearance of the enterprise, customers' premises, WC, staff, menu, and food and drink quality. In each of the sections, criteria were set which were used to provide assessment on a 5 -point scale, where $5=$ very good; 4 = good; $3=$ average; $2=$ unsatisfactory; $1=$ weak. The 21 company that was evaluated corresponds to different categories of the catering businesses, therefore, the results were analysed separately for each group of the enterprises. In this article, only restaurants, general type cafés and specialised cafés are analysed, as there are only a few other types of companies, and analysing them would infringe the data confidentiality. Only summarised results are presented providing an average indicator for a particular type of the company (Fig.2).

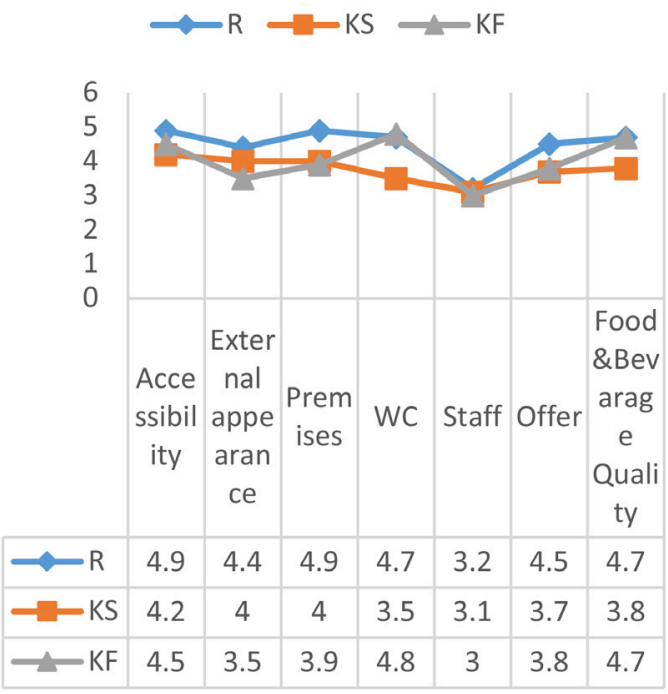

Fig.2. Quality assessment of Rezekne city catering companies (by the authors based on the observation data)

* $\mathrm{R}$ - restaurant; KS - specialised café; KF - general type café 
Criteria to assess accessibility: signs for visitors, parking facilities, accessibility by public transport. The average evaluation is higher (4.9) for the restaurant-type catering establishments, as they are located in the city centre, on the main street, within 300 meters from each other. Specialised cafés are situated throughout the city and have different accessibility, as a result, the average assessment is the lowest (4.2). The company's external appearance was assessed using criteria such as first impression, facade signboard, entrance appearance, and menu at the entrance, references to the special offers and opening hours. The lowest results (3.5) are for general type cafés, as several cafés are located in the residential blocks or business buildings that are not owned by the caterers, so they are not free to place advertisements or make facade repairs and renovations. Customer's premises are characterized by criteria such as first impression, room ambience, overall cleanliness, equipment compliance with the company type, lighting, air quality, noise and other disturbances. The lowest assessment is in general type cafés (3.9), though, it is not particularly high in specialised cafés as well (4.0). Air quality was the most significant factor determining the assessment, as, in many catering companies, the smell of the kitchen could be felt and the overall cleanliness shall be at the higher level. The WC facilities were assessed by criteria such as cleanliness, quality of equipment, accessibility for people with reduced mobility. The overall rating is the lowest in specialised cafés (3.5). In some of them, the cleaning is done regularly, as evidenced by the records in the cleaning schedule, but given the number of customers, this should be done more frequently. In general, almost in all catering establishments of this type, the WC equipment have a high degree of wear and tear. The staff assessment included a large number of evaluation criteria, but they were divided according to the type of catering company, because what is permissible in a general or specialized café is not allowed in a restaurant. These criteria included employee's skills, professional competencies, knowledge, clothing, customer service, etc. The results for all three categories of catering companies were relatively low. In general, among all 7 evaluation sections, this one shows the lowest results. This means that the companies need to consider very seriously the training of their employees and raising their qualifications. In fact, it is a critical point in the customer service. The offer was assessed by criteria such as menu, readability, content, description of ingredients, size of meal, daily or special offers, as well as the same regarding drink menu. The type of company was taken into account in the assessment. In general type and specialized cafés the result is similar (3.8 and 3.7, respectively). The results were significantly influenced by the menu contents and description of ingredients, and special offers. In fact, the rated companies have no offer for people with special dietary requirements. Food and beverage quality was assessed by criteria such as serving temperature, visual appearance, quality, taste compatibility, etc. The specialised cafés have the lowest evaluation in this category (3.8). The main drawbacks that affected the assessment results were match of dish and meal size, as well many companies do not comply with the food and beverage serving temperatures.

\section{CONCLUSIONS}

The prevalence of eating out is increasing in an industry offering a diverse range of outlets, commonly classified into two sectors: profit, private or commercial; and cost, public or welfare/institutional sector. The foodservice industry is an integral and growing component of most economies and therefore offers a vast number of opportunities.

Eating and dining outside involves more than simply matching meals with consumers and the consumption of food; but a myriad or other factors, which can affect choice of the catering establishment by the customer.

There are different types and names of catering establishments, still, the public catering develops its professional orientation mostly due to the development of the customers' fast-service system in its all possible manifestations.

In current market conditions (demanding and selective customers, fierce competition), creative and innovative catering companies will survive and develop. Though, for this to happen, the human resource (a team that develops and builds a catering company) with the necessary competencies in marketing, design, and management is crucial.

Therefore, as a result of this study, it can be concluded that the research hypothesis has been confirmed. A significant part of the surveyed companies have not correctly defined their type of the catering service, as a result, the offer is not properly developed and does not coincide with the expectations of the customers thus affecting the quality of service.

\section{REFERENCES}

[1] The Statistics Portal, "Food \&Beverages", 2019, [Online]. Available: https://www.statista.com/outlook/253/100/food-beverages/ worldwide\#market-revenue [Accessed: Feb.12, 2019].

[2] Euromonitor International, "Global apparel and footwear valued at US\$1.7 trillion in 2017, yet millions of used clothing disposed of every year.", May.3, 2018.[Online]. Available: https://blog. euromonitor.com/global-apparel-footwear-valued-us-1-7-trillion2017-millions-of-used-clothing-disposed-every-year/ [Accessed: Feb.20, 2019].

[3] I. Silicka and I. Dembovska, "Research into catering enterprise service and its quality analysis in Rezekne", Journal of Social Sciences. Latgale National Economy Research., Vol 1, No 5, pp.180202, June 2013.

[4] J.S.A. Edwards, "The foodservice industry:Eating out is more than just a meal". Food Quality and Preference, vol. 27, no.2, pp. 223-229, March 2013. [Online]. Available: https://www.researchgate.net/publication/257390189 The foodservice industry Eating out is more than just a meal. [Accessed Jan.23, 2019], DOI: $10.1016 /$ j.foodqual.2012.02.003

[5] J. Paddock, A. Warde and J. Whillans, "The changing meaning of eating out in three English cities 1995-2015". Appetite, vol. 119, pp. 5-13, January 2017. [Online]. Available: https://www.researchgate.net/publication/313128113 The changing meaning of eating out in three English cities 1995-2015. [Accessed Jan.28, 2019], ttp://dx.doi.org/10.1016/j.appet.2017.01.030

[6] C.Diaz-Mendez and I.Garcia-Espejo, "Eating out in Spain: Motivations, sociability and consumer contexts". Appetite, vol.119, pp.14-22, January 2017. http://dx.doi.org/10.1016/j. appet.2017.03.047

[7] T.B. Lund, U.Kjaernes and L.Holm. "Eating out in four Nordic 
countries: National patterns and social stratification". Appetite,vol 119, pp.23-33, January 2017.[Online]. Available: https:// www.researchgate.net/publication/330893611 Satisfaction of nutritionists_who_work_in_food_service [Accessed Feb.2, 2019], http://dx.doi. org/10.1016/j.appet.2017.06.017

[8] A.G. Smith and A.West, Catering Systems. Oxford: Catering Elsevier Science, UNEP, 2003.

[9] B.Davis, A. Lockwood, and s. Stone, Food and Beverage Management. Oxford: Butterworth-Heinemann, 1998.

[10] Tūrisma un viesmīlības terminu skaidrojošā vārdnīca. Rīga: LR Ekonomikas ministrija, 2008.

[11] D. Lillicrapand and J. Cousins, Food and beverage service. London: Hodder Education an Hachette UK Company, 2010.

[12] M.A. Bourlakis and P.W.H. Weightman, Food Supply Chain Management. Oxford: Blackwell Publishing, 2004.

[13] Toxel.com, "10 unusual and creative restaurants", June 2009. [Online]. Available http://www.toxel.com/inspiration/2009/06/20/10-unusual-and-creative-restaurants/ [Accessed March 4, 2019].

[14] J. S. A. Edwards and H. J. Hartwell, "Institutional meals". In H. L. Meiselman (Ed), "Meals in science and practice. Interdisciplinary research and business applications". Oxford: CRC Press, Woodhead Publishing, 2009, pp. 102-127.

[15] J. Sjomina, Darba organizācija ēdināšanas uzṇēmumos. Rīga: RTU, 2011.
[16] В.В.Усов, Организация производства и обслуживания на предприятиях общественного питания. Москва: Академия, 2009.

[17] I. Millere, Ēdināšanas uzṇēmumu teorētiskie un klasifikācijas aspekti. Darbības procesi ēdināšanas uzṇēmumos Latvijas reǵionos. Jelgava: LLU, 2009.

[18] N. Johns and R. Pine, "Consumer behaviour in the food service industry:a review". Hospitality Management, vol. 21, pp. 119-134, 2002.[Online]. Available: https://wenku.baidu.com/ view/2f0d01b0fd0a79563c1e72df.html [Accessed Feb.23, 2019].

[19] A. Pizam and T. Ellis, "Customer satisfaction and its measurement in hospitality enterprises". International Journal of Contemporary Hospitality Management, vol 11, no7,pp. 326-339, December 1999. [Online]. Available: https://www.researchgate.net/publication/235296583 Customer satisfaction and its measurement in hospitality enterprises [Accessed Dec.22, 2018], DOI: 10.1108/09596119910293231

[20] I.Silicka, "Eksperta anketa". Rēzeknes Augstskolas ESF projekts „Profesionālas pilnveides programmu izstrāde un īstenošana viesmīlības nozares sabiedriskās ēdināšanas uznēmumu darbiniekiem", 2014 